\title{
A novel de novo KDM5C variant in a female with global developmental delay and ataxia: a case report
}

\author{
Natalie C. Lippa', Subit Barua², Vimla Aggarwal², Elaine Pereira ${ }^{3}$ and Jennifer M. Bain ${ }^{4^{*}}$ (D)
}

\begin{abstract}
Background: Pathogenic variants in KDM5C are a cause of X-linked intellectual disability in males. Other features in males include short stature, dysmorphic features, seizures and spasticity. In some instances, female relatives were noted to have learning difficulties and mild intellectual disabilities, but full phenotypic descriptions were often incomplete. Recently, detailed phenotypic features of five affected females with de novo variants were described. (Clin Genet 98:43-55, 2020) Four individuals had a protein truncating variant and 1 individual had a missense variant. All five individuals had developmental delay/intellectual disability and three neurological features.

Case presentation: Here we report a three-year-old female with global developmental delay, hypotonia and ataxia. Through whole exome sequencing, a de novo c.1516A > G (p.Met506Val) variant in KDM5C was identified. This missense variant is in the jumonji-C domain of this multi domain protein where other missense variants have been previously reported in $\mathrm{KDM} 5 \mathrm{C}$ related disorder. The $\mathrm{KDM} 5 \mathrm{C}$ gene is highly intolerant to functional variation which suggests its pathogenicity. The probands motor delays and language impairment is consistent with other reported female patients with de novo variants in KDM5C. However, other features reported in females (distinctive facial features, skeletal abnormalities, short stature and endocrine features) were absent. To the best of our knowledge, our proband is the first female patient reported with a diagnosis of ataxia.
\end{abstract}

Conclusions: This case report provides evidence for an emerging and phenotypic variability that adds to the literature of the role of KDM5C in females with neurodevelopmental disorders as well as movement disorders.

Keywords: Ataxia, Neurodevelopmental disorder, KDM5C, Intellectual disability, Case report

\section{Background}

The lysine specific demethylase $5 \mathrm{C}(\mathrm{KDM} 5 \mathrm{C})$ is a cause of X-linked intellectual disability (ID) in males (Mental retardation, X-linked, syndromic, Claes-Jensen type; MIM\# 300534). The gene was first described to cause disease in 2005 by Jensen et al. who identified seven KDM5C variants in 20 affected males from 7 families through a mutational screen of brain expressed genes on the $\mathrm{X}$ chromosome in a cohort of families with X-linked

\footnotetext{
* Correspondence: jb3634@cumc.columbia.edu

${ }^{4}$ Department of Neurology, Columbia University Irving Medical Center, New York, NY, USA

Full list of author information is available at the end of the article
}

ID [1]. Following this initial publication, additional reports were published linking this gene to disease $[2,3]$. These reports indicated that some proband's mothers and other female relatives who carried the $K D M 5 C$ variant could also be affected, but the phenotypic descriptions were lacking.

The first de novo variant reported in a female was identified in a patient with spastic diplegia, speech dyspraxia and ID through trio exome sequencing [4]. The second case was a presumed de novo (dad unaffected but unavailable for testing) $0.4 \mathrm{Mb}$ deletion encompassing six genes in a female with severe ID, no speech and autism spectrum disorder among other findings [5].

(c) The Author(s). 2021 Open Access This article is licensed under a Creative Commons Attribution 4.0 International License, which permits use, sharing, adaptation, distribution and reproduction in any medium or format, as long as you give appropriate credit to the original author(s) and the source, provide a link to the Creative Commons licence, and indicate if changes were made. The images or other third party material in this article are included in the article's Creative Commons licence, unless indicated otherwise in a credit line to the material. If material is not included in the article's Creative Commons licence and your intended use is not permitted by statutory regulation or exceeds the permitted use, you will need to obtain permission directly from the copyright holder. To view a copy of this licence, visit http://creativecommons.org/licenses/by/4.0/. The Creative Commons Public Domain Dedication waiver (http://creativecommons.org/publicdomain/zero/1.0/) applies to the data made available in this article, unless otherwise stated in a credit line to the data. 
Recently, Carmignac et al. reported on 19 females carrying 10 novel heterozygous variants, and a wider phenotypic spectrum of the female phenotype emerged [6]. The authors found that all affected individuals presented with learning disabilities or ID, with four also having language impairment. Four of the 19 female carriers were asymptomatic. Interestingly, the authors reported on 5 female patients referred for ID who were found to have a de novo protein-truncating-variants or missense variants. This is largest cohort of female patients reported with de novo variants in this gene.

We report a novel de novo KDM5C missense variant (c.1516A > G, p.Met506Val) in a 3-year-old female with global developmental delay, hypotonia and ataxia.

\section{Case presentation}

A 3-year-old female with ataxia, hypotonia and global developmental delay was referred for a neurological evaluation. The proband was conceived naturally, and pregnancy was uncomplicated. She was born full term at 39 weeks gestation via emergent $\mathrm{C}$-section for fetal distress with normal birth parameters [weight $6 \mathrm{lbs}$. $9 \mathrm{oz}$. (25th percentile), length 20 in (75th percentile) and head circumference $33.5 \mathrm{~cm}$ (25th percentile)]. There were no medical issues or concerns in the newborn period other than a tongue and lip tie which caused feeding issues and was subsequently corrected.
The proband sat at 7 months and walked at 15 months but had significant expressive language impairment; her first word was at 23 months old of age and her speech pattern was notable for scanning speech prosody. During the neurological evaluation at 3 years old, cerebellar findings included dysmetria and wide based jerky gait and she was diagnosed with ataxia. She also was noted to have some anxiety as well by parental report. See Table 1 for EEG, genetic tests and neuropsychological results. MRI was not completed and family history was non-contributory.

The proband and her parents were referred to and enrolled into an IRB approved research whole exome sequencing protocol after signing informed consent (CUIMC IRB \# AAAO6702). DNA was extracted from maternal, paternal, and proband blood samples. Libraries were prepared using Kapa Hyper Prep Kit, exome captured with IDT xGen Exome Research Panel v1 and sequenced on the NovaSeq6000. Our process for the filtering and prioritization of variants has been described previously [7]. A de novo missense variant (X-53239925-T-C [GrCh37); c.1516A > G; p.Met506Val) was identified in the KDM5C gene in the proband. The presence/absence of the variant was clinically confirmed via Sanger sequencing in the proband, mother and father in a CLIA-approved laboratory [8].

Table 1 EEG, Genetic Testing and Neuropsychological results

\begin{tabular}{|c|c|c|}
\hline Evaluations & $\begin{array}{l}\text { Age at } \\
\text { test date }\end{array}$ & Result \\
\hline Ambulatory EEG & 3 years & Normal \\
\hline Chromosome Analysis & 3 years & Normal $(46 X X)$ \\
\hline Microarray & 3 years & Normal \\
\hline Fragile X & 3 years & Normal (29 and 32 CGG repeats) \\
\hline MECP2 seq + del/dup & 3 years & Normal \\
\hline Trio WES & 3 years & $\begin{array}{l}\text { De novo missense variant in the KDM5C gene } \\
\text { (g.X-53239925 T > C; c.1516A > G; p.Met506Val; NM_004187.4) }\end{array}$ \\
\hline $\begin{array}{l}\text { Wechsler Preschool and Primary } \\
\text { Scale of Intelligence - IV }\end{array}$ & $\begin{array}{l}2 \text { years } 8 \\
\text { months }\end{array}$ & $\begin{array}{l}\text { Full Scale Intelligence Quotient }(\mathrm{IQ})=85 \text { (Low Average range) } \\
\text { General Ability Index }=91 \text { (Average range) } \\
\text { Vocabulary Acquisition Index }=75 \text { (Borderline range) }\end{array}$ \\
\hline Vineland 3 & $\begin{array}{l}2 \text { years } 8 \\
\text { months }\end{array}$ & $\begin{array}{l}\text { Adaptive Behavior Composite }=70 \text { (percentile rank }=2 \text { ) } \\
\text { Communication Domain }=72 \text { (percentile rank }=3 \text { ) } \\
\text { - The communication domain is made up of two subdomains: Expressive and Receptive. The } \\
\text { probands score was adequate for receptive and low for expressive domains. The probands } \\
\text { receptive score is significantly higher than the expressive score. } \\
\text { Daily Living Skills Domain }=75 \text { (percentile rank }=5 \text { )) } \\
\text { Socialization Domain }=65 \text { (percentile rank }=1 \text { ) } \\
\text { Motor Skills Domain = } 55 \text { (percentile rank }<1 \text { ) } \\
\text { - The motor domain is made of two subdomains Gross and Fine Motor. The probands gross } \\
\text { motor was moderately low and fine motor score was low. The gross motor was significantly } \\
\text { higher than fine motor }\end{array}$ \\
\hline Childhood Autism Rating Scales 2 & $\begin{array}{l}2 \text { years } 8 \\
\text { months }\end{array}$ & Raw Score $=28.5$ (Minimal to no symptoms of Autism Spectrum Disorder) \\
\hline
\end{tabular}

${ }^{a}$ Misleading as it represents only rote receptive skills and not communicative ability 


\section{Discussion and conclusions}

In this study, we implicate a novel de novo variant, p.Met506Val, as disease causing in the KDM5C gene. To the best of our knowledge, this is only the third female proband identified to harbor a de novo missense variant. Our findings with the neuropsychological tests extend the knowledge of clinical manifestation associated with this rare disorder, by describing a female proband with a KDM5C variant showing low average IQ but significant deficiencies in motor and other adaptive skills. Additionally, this is the first report of a female proband with ataxia.

The c.1516A > G variant is a single base pair substitution in exon 11 of 26 of the KDM5C gene, which causes a substitution of Methionine to Valine at position 506 (506 of 1561) in the jumonji-C domain of this multi domain protein where other missense variants have been previously reported in $K D M 5 C$ related disorders [6]. Jumonji-C domain is the catalytic core for histone H3K4 demethylation and interaction between the JmjC domain is important for the demethylation activity $[9,10]$. This c.1516A > G variant is absent from the Genome Aggregation Database (gnomAD) [11] and it meets the hotzone specific bioinformatics signature described in $\mathrm{Zhu}$ et al. [7]. Additionally, this KDM5C gene is highly intolerant to functional variation with a pLI score of 1 and a Z-score of 5.15 [11]. Moreover, the CADD (score:25.1; GRCh37-v1.6) and REVEL score (score:0.785; version 4.1) also suggests the variants pathogenicity [12, 13]. Taken together, the evidence supports that the p.Met506Val in KDM5C is a strong candidate for disease causation in our proband. This additional variant in KDMC5 may demonstrate a broader phenotypic spectrum than other genotypes previously reported in the literature (Fig. 1).

There are some notable limitations of this study. First, we cannot exclude a digenic model for this phenotype as other variants have been previously reported with ataxia. We would propose a phenotype spectrum, as opposed to strict genotype-phenotype correlations, especially in the setting of an X-linked disorder. Another limitation is that we have not performed $\mathrm{X}$-inactivation studies to assess whether there was any skewing may have contributed to the phenotype. Further studies to study other epigenic mechanisms may provide a better understanding of the pathophysiology leading to a broader phenotypic spectrum. Importantly, many genetic causes of ataxia are due to expansions such as trinucleotide repeats. While the subject did have FMR repeat testing for Fragile $\mathrm{X}$ syndrome, no other repeat expansions were specifically evaluated for as our research study program uses whole exome sequencing strategy for finding causative variants.

Our proband has similar features to other similarly reported female patients with de novo variants in KDM5C, presenting with motor delay and language impairment, notably on expressive speech. Other affected female have motor impairments, including oro-facial dyspraxia, oculo-manual coordination difficulties, spasticity and hyperreflexia. Interestingly, our proband does not have any other features that have been reported including a distinctive facial features, skeletal abnormalities, short stature and endocrine features. This could be related to age since some of these features may present in later years. It could also indicate the emerging and variable phenotype associated with $K D M 5 C$ variants in females. This concept is supported by a previous report of a de novo missense variant in $K D M 5 C$ identified in a patient with cerebral palsy [4]. Consistent with this theory is the fact that our proband presented with ataxia at the age of 3 years. To our knowledge, there is no other female patient that has been reported to have a diagnosis of ataxia. There is a report of one family where the male patients had ataxia but interestingly, the affected female relatives were not noted to have this symptom [14].

In conclusion, our case report is consistent with previous reports of language delay as common features in females with $K D M 5 C$ disease causing variants. The detailed neuropsychological testing indicate that our probands motor skills are much more severely affected

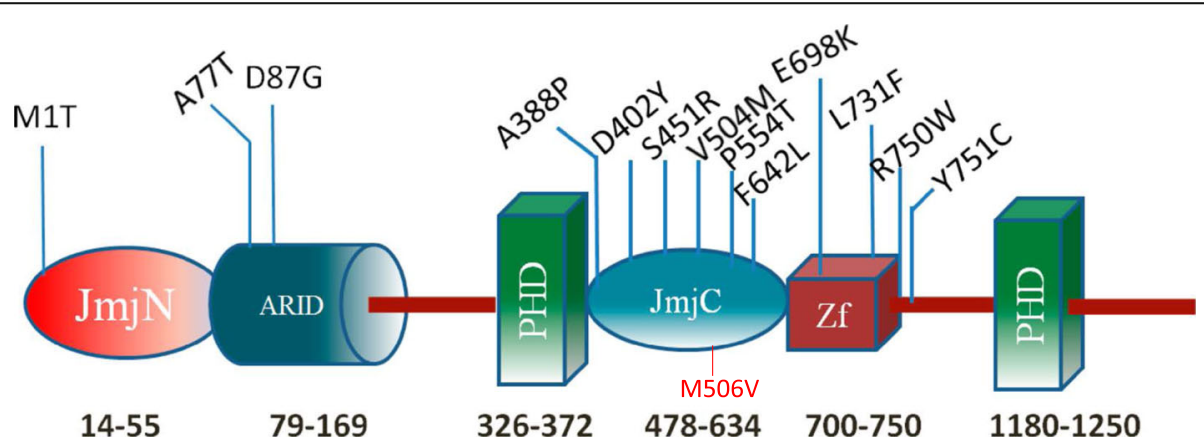

Fig. 1 KDM5C protein domains (as shown in PMID\# 26580603). The numbers indicate approximate domain boundaries. The known diseaseassociated missense variants are provided as well. Variant seen in our case is shown in red 
than her IQ. Moreover, this case report expand the clinical landscape by reporting a female proband with ataxia who harbors a novel de novo variant in KDM5C. Overall, this case report further confirm that distinctive facial features, skeletal abnormalities, short stature and endocrine features can be absent in $K D M 5 C$ related disorders. This provides evidence for an emerging and phenotypic variability that adds to the literature of the role of $K D M 5 C$ in females with neurodevelopmental disorders.

\section{Abbreviations}

gnomAD: Genome Aggregation Database; ID: Intellectual disability; KDM5C: Lysine specific demethylase 5C

\section{Acknowledgements}

The authors would like to thank the proband and her family for participating in this study.

\section{Authors' contributions}

$\mathrm{NL}$ contributed to the analysis of genomic WES data, writing the manuscript and data extraction from the medical records. J.B. is the probands primary neurologist and initially examined the proband. EP examined and followed up with the proband after the KDM5C diagnosis. S.B. and V. A provided oversight of the work done in the clinical laboratory. All authors revised, contributed intellectually and approved the final version of the manuscript.

\section{Funding}

The research WES and clinical confirmation was internally funded. The proband and her family had their initial research visit in the CUIMC Clinical Research Resource which is supported by the National Center for Advancing Translational Sciences, National Institutes of Health, through Grant Number UL1TR001873. The content is solely the responsibility of the authors and does not necessarily represent the official views of the $\mathrm{NIH}$.

\section{Availability of data and materials}

Not applicable.

\section{Declarations}

\section{Ethics approval and consent to participate}

Written informed consent to participate was obtained from the probands parent to participate in the research WES protocol and to allow the findings to be published. The study was approved by the CUIMC IRB (Protocol AAAO6702).

\section{Consent for publication}

Written informed consent to publish these findings was obtained from all participants or from a parent for participants under 18 years old.

\section{Competing interests}

The authors declare they have no competing interests.

\section{Author details \\ ${ }^{1}$ Institute for Genomic Medicine, Columbia University Irving Medical Center, New York, NY, USA. ${ }^{2}$ Department of Pathology and Cell Biology, Columbia University Irving Medical Center, New York, NY, USA. ${ }^{3}$ Department of Pediatrics, Columbia University Irving Medical Center, New York, NY, USA. ${ }^{4}$ Department of Neurology, Columbia University Irving Medical Center, New York, NY, USA.}

Received: 24 November 2020 Accepted: 2 September 2021 Published online: 16 September 2021

\section{References}

1. Jensen LR, Amende M, Gurok U, Moser B, Gimmel V, Tzschach A, et al. Mutations in the JARID1C gene, which is involved in transcriptional regulation and chromatin remodeling, cause X-linked mental retardation. Am J Hum Genet. 2005;76(2):227-36.

2. Santos C, Rodriguez-Revenga L, Madrigal I, Badenas C, Pineda M, Mila M. A novel mutation in JARID1C gene associated with mental retardation. Eur J Hum Genet. 2006;14(5):583-6.

3. Abidi FE, Holloway L, Moore CA, Weaver DD, Simensen RJ, Stevenson RE, et al. Mutations in JARID1C are associated with X-linked mental retardation, short stature and hyperreflexia. J Med Genet. 2008:45(12):787-93.

4. McMichael G, Bainbridge MN, Haan E, Corbett M, Gardner A, Thompson S, et al. Whole-exome sequencing points to considerable genetic heterogeneity of cerebral palsy. Mol Psychiatry. 2015;20(2):176-82

5. Fieremans N, Van Esch H, de Ravel T, Van Driessche J, Belet S, Bauters M, et al. Microdeletion of the escape genes KDM5C and IQSEC2 in a girl with severe intellectual disability and autistic features. Eur J Med Genet. 2015; 58(5):324-7.

6. Carmignac V, Nambot S, Lehalle D, Callier P, Moortgat S, Benoit V, et al. Further delineation of the female phenotype with KDM5C disease causing variants: 19 new individuals and review of the literature. Clin Genet. 2020; 98(1):43-55.

7. Zhu X, Petrovski S, Xie P, Ruzzo EK, Lu YF, McSweeney KM, et al. Wholeexome sequencing in undiagnosed genetic diseases: interpreting 119 trios. Genet Med. 2015:17(10):774-81.

8. Richards S, Aziz N, Bale S, Bick D, Das S, Gastier-Foster J, et al. Standards and guidelines for the interpretation of sequence variants: a joint consensus recommendation of the American College of Medical Genetics and Genomics and the Association for Molecular Pathology. Genet Med. 2015; 17(5):405-24.

9. Iwase S, Lan F, Bayliss P, de la Torre-Ubieta L, Huarte M, Qi HH, et al. The Xlinked mental retardation gene SMCX/JARID1C defines a family of histone H3 lysine 4 demethylases. Cell. 2007;128(6):1077-88.

10. Huang F, Chandrasekharan MB, Chen YC, Bhaskara S, Hiebert SW, Sun ZW. The JmjN domain of Jhd2 is important for its protein stability, and the plant homeodomain (PHD) finger mediates its chromatin association independent of H3K4 methylation. J Biol Chem. 2010;285(32):24548-61.

11. Karczewski KJ, Francioli LC, Tiao G, Cummings BB, Alfoldi J, Wang Q, et al. The mutational constraint spectrum quantified from variation in 141,456 humans. Nature. 2020:581(7809):434-43.

12. Rentzsch P, Witten D, Cooper GM, Shendure J, Kircher M. CADD: predicting the deleteriousness of variants throughout the human genome. Nucleic Acids Res. 2019;47(D1):D886-D94.

13. Ioannidis NM, Rothstein JH, Pejaver V, Middha S, McDonnell SK, Baheti S, et al. REVEL: an ensemble method for predicting the pathogenicity of rare missense variants. Am J Hum Genet. 2016;99(4):877-85.

14. Brookes E, Laurent B, Ounap K, Carroll R, Moeschler JB, Field M, et al. Mutations in the intellectual disability gene $\mathrm{KDM} 5 \mathrm{C}$ reduce protein stability and demethylase activity. Hum Mol Genet. 2015;24(10):2861-72.

\section{Publisher's Note}

Springer Nature remains neutral with regard to jurisdictional claims in published maps and institutional affiliations.

Ready to submit your research? Choose BMC and benefit from:

- fast, convenient online submission

- thorough peer review by experienced researchers in your field

- rapid publication on acceptance

- support for research data, including large and complex data types

- gold Open Access which fosters wider collaboration and increased citations

- maximum visibility for your research: over $100 \mathrm{M}$ website views per year

At $B M C$, research is always in progress.

Learn more biomedcentral.com/submission 